\title{
THE STUDY OF BUSINESS CENTERS IN THE ARABIAN GULF: RESIDENTIAL, OFFICES, AND COMMERCIAL BUILDINGS
}

\author{
A.D. Razin, Z.Sh. Alhalabi, I. Khalil \\ Peoples' Friendship University of Russia (RUDN University) \\ Miklukho-Maklaya str., 6, Moscow, Russia, 117198
}

The modern architecture of the Arabian Gulf has become an international icon after the completion of Burj Al Arab in 1999. Since then, many more modern buildings were built in order to host the numerous international companies residing or branching in the Arabian Gulf especially in Dubai.

This article will examine few examples of the modern architecture the Arabian Gulf, some of many amazing projects were constructed, alongside a brief introduction, what challenges the architecture faces in the Arabian Gulf, and what's the future seems like.

Key words: Commercial buildings, offices, Middle East, Dubai, Arabian Gulf, architecture, and carbon critical design

\section{INTRODUCTION}

The Arabian Gulf has become one of the popular international business hubs. With thousands of foreign businesses taking place in that geographical spot, the architecture of that region has changed rapidly and immensely in order to provide the adequate place to host all these businesses and all the facilities needed for those who run them.

One of the things that make the architecture of the Arabian gulf unique is the zest for excellence, they take environmental measurements and sustainability into consideration so they have Carbon Critical Designs which aims to decrease the carbon emission levels during construction as well afterwards; Carbon Critical Designs is a layer of the multiple layers sustainable design and it's rather an important one. This is a big step due to the fact that climate change is partially caused by manmade carbon emissions.

\section{MODERN ARCHITECTURE IN THE ARABIAN GULF}

The first building to ever be built in the Middle East which has an international fame is Burj $\mathrm{Al}$ Arab and it's one of the most important projects for this region, its importance comes from the change caused by it. In 1999 the construction of Burj Al Arab was completed putting Dubai in the international spotlight as it amazed the world with the simple iconic design; which in its turn turned Dubai into an international tourism destination and a modern city.

\subsection{Urban Architecture in Dubai}

Dubai's urban master plan has changed drastically in the past 20 years, changing from a modest city into an international icon of modern architecture. One of the main features 


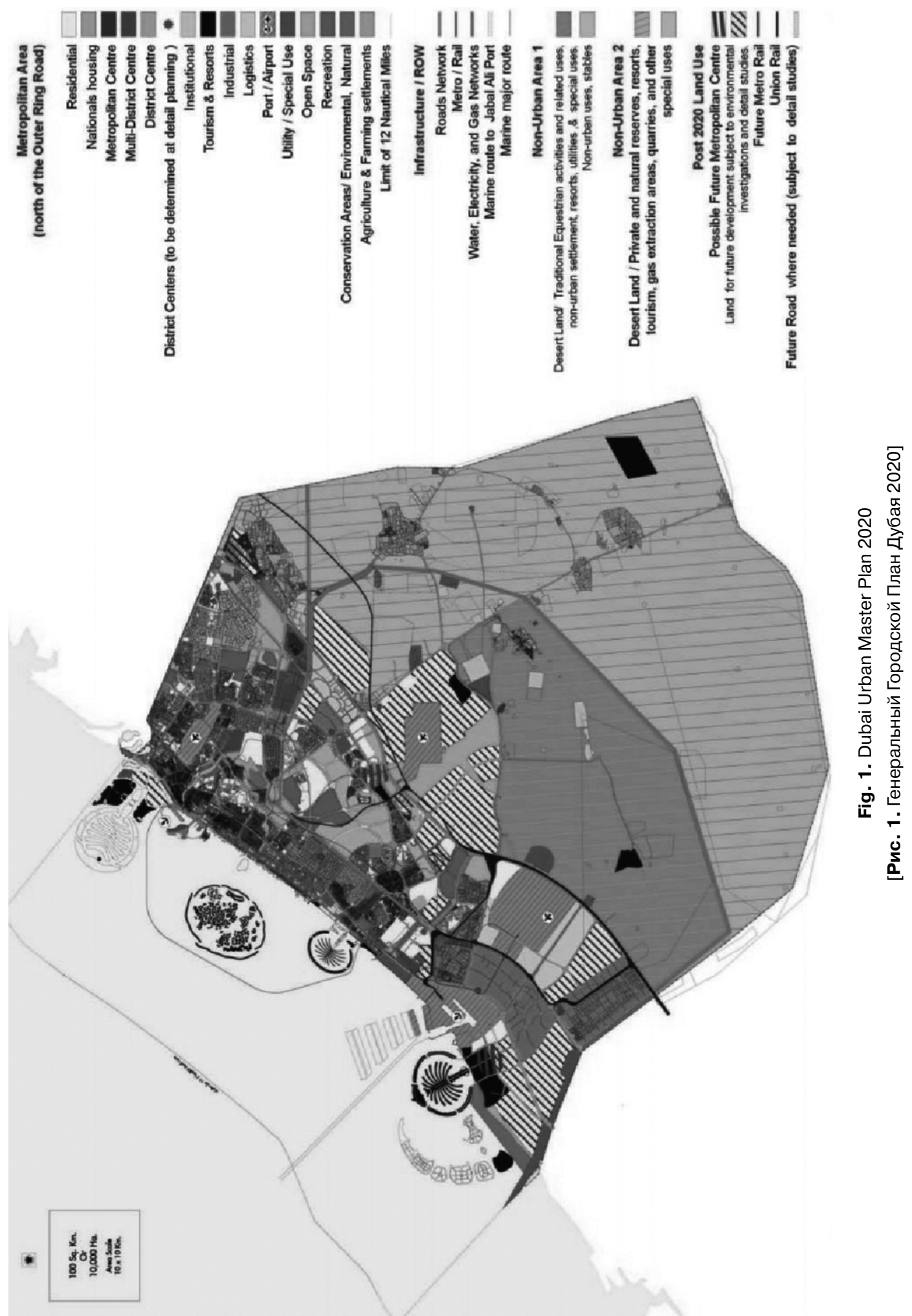


of Dubai's urban planning is the artificial islands, which provided a solution to the limited land problem as the total area of Dubai is $4,114 \mathrm{~km}^{2}$ while the population of 2.657 million (5 Nov. 2016). As noticed below (fig. 1) Dubai's metropolitan center is divided into two parts; both parts are surrounded by residential areas from behind while maintaining some residential areas integrated within the metropolitan centers. On the other hand, major tourism zones are located in three main parts by the sea; two of them are adjacent to the two parts of the metropolitan center. It is noticed that each of the city's two international airports is located near one of the two parts of the metropolitan center while the sea port is located between two major tourist areas.

\subsection{Offices and Commercial Buildings}

After the construction of Burj Al Arab, the Arabian Gulf was brought to life and became an attraction for international businesses bringing a new demand for offices and commercial buildings. Since then, many projects have been designed and constructed in the Arabian Gulf some of which are the following:

\subsection{Al Rostamani Office and Residential Building}

The building was completed in 2005, just one year after the beginning of its construction in 2004. It is located in the midst of the banking district of Dubai, UAE. The tower contains 4 commercial floors in addition to a banking hall on the ground floor; the 9 upper floors are residential and are separated from the commercial floors. The total floor count is 16 overground and 3 underground, with a total height of $79 \mathrm{~m}$. The design represents a float and has curved beautiful lines providing a pleasant view of the city (fig. 2), and is considered to have a postmodernism architectural style.

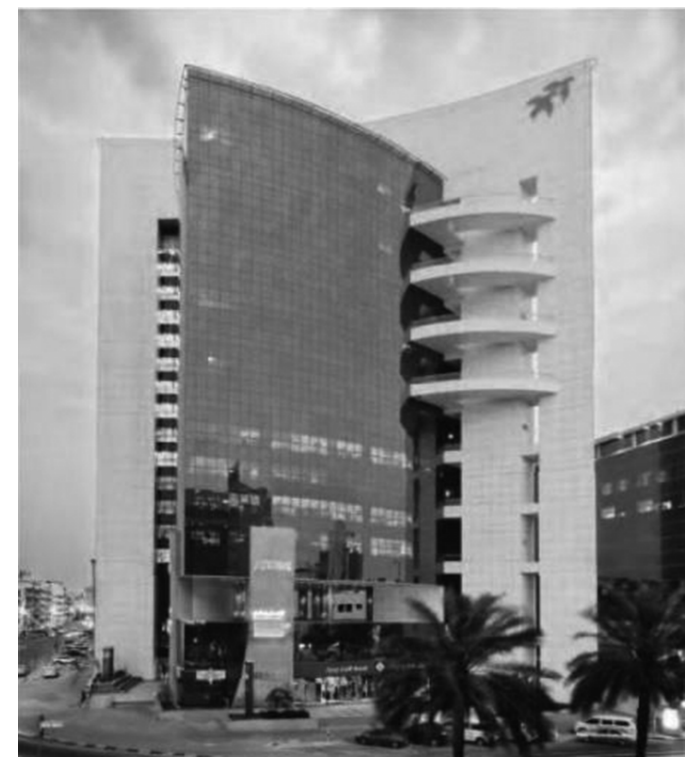

Fig. 2. Al Rostamani Office and Residential Building, Dubai, UAE, 2005

[Рис. 2. Аль Ростамани офисные и жилые здания, Дубай, ОАЭ, 2005] 


\subsubsection{Tiffany Tower}

The Tiffany Tower is located in Dubai, UAE within the Jumeirah Lake Towers, which is a new district "New Dubai". It's made up of 79 towers arranged in 3 groups of towers in form of lakes. The simple elegant curvy design from the outside (fig. 3) surrounds a rectangular plan on the inside (fig. 4). The $183 \mathrm{~m}$ high building is made of 41 floors above ground and contains 3 floors of retail and restaurant outlets while having 38 floors of offices and guest suites on the upper levels. The construction started in 2005 and was completed in 2010 .

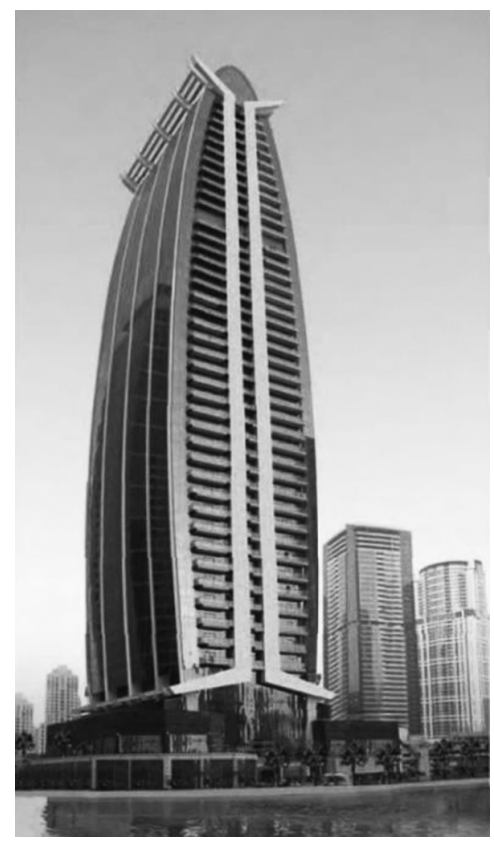

Fig. 3. Tiffani Tower, Dubai, UAE, 2010

[Рис. 3. Башня Тиффани, Дубай, ОАЭ, 2010]

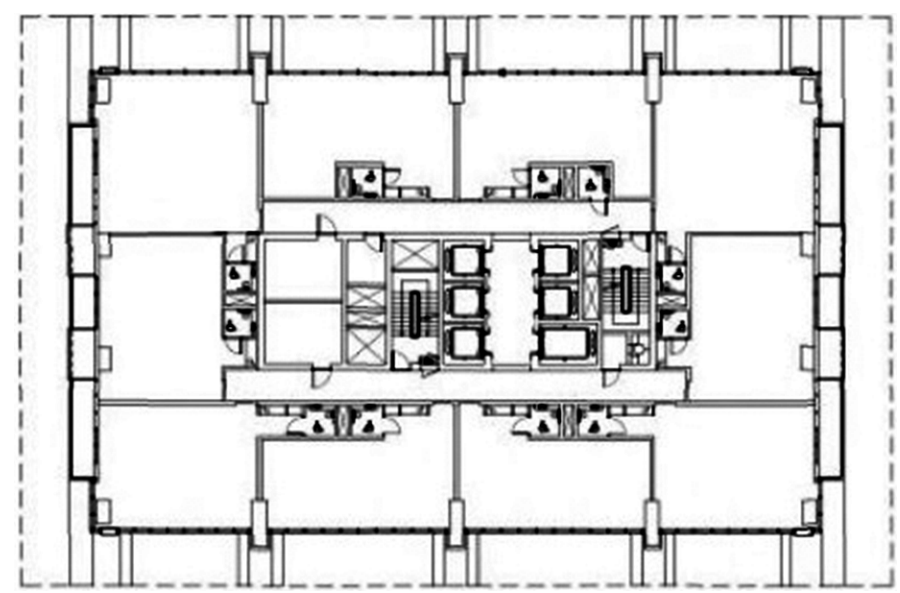

Fig. 4. A Typical Floor Plan (3-19)

[Рис. 4. Типичный план этажа (3-19)] 


\subsubsection{DSEC Commercial Tower}

This commercial tower (fig. 6) was completed in 2010 and is located in the center of the business district of Dubai, UAE. It contains 19 office floors with underground parking for 650 cars. The building hosts restaurants and retail stores within the first three floors while the roof is a leisure center including a gym, swimming pool and relaxation decks that provide a wonderful view of the city.

The building consists of a glazed box of offices (fig. 5) enveloped by an ovoid cylinder lifted beautifully above the ground which divides the external design into two main elements; the podium and the tower (fig. 7).

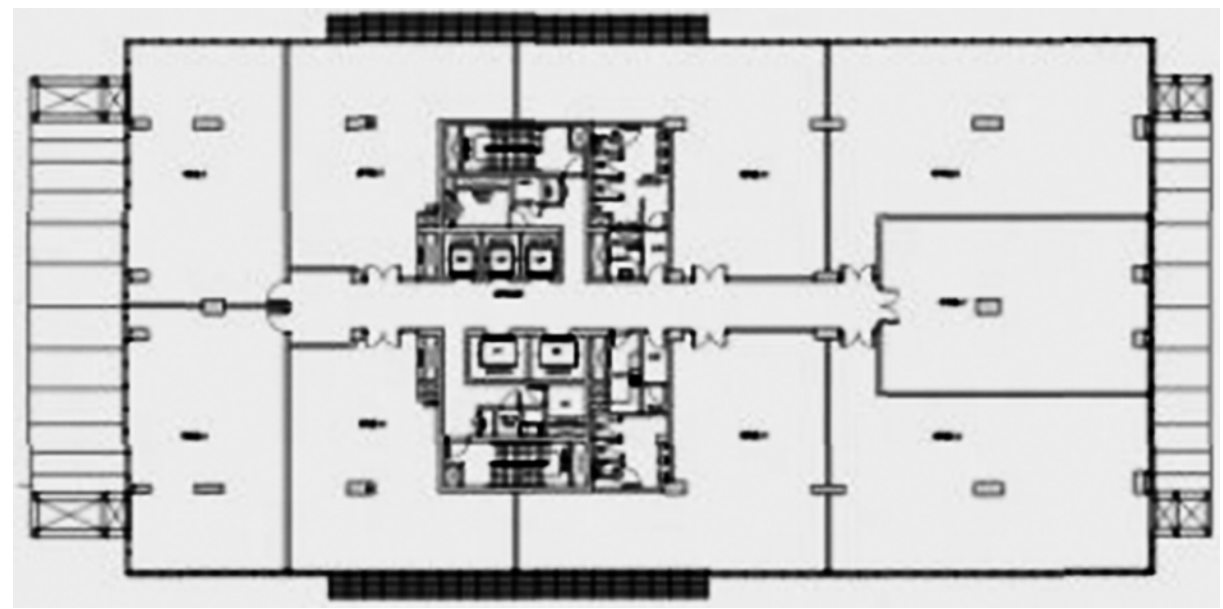

Fig. 5. A Typical Floor Plan

[Рис. 5. Типичный план этажа]
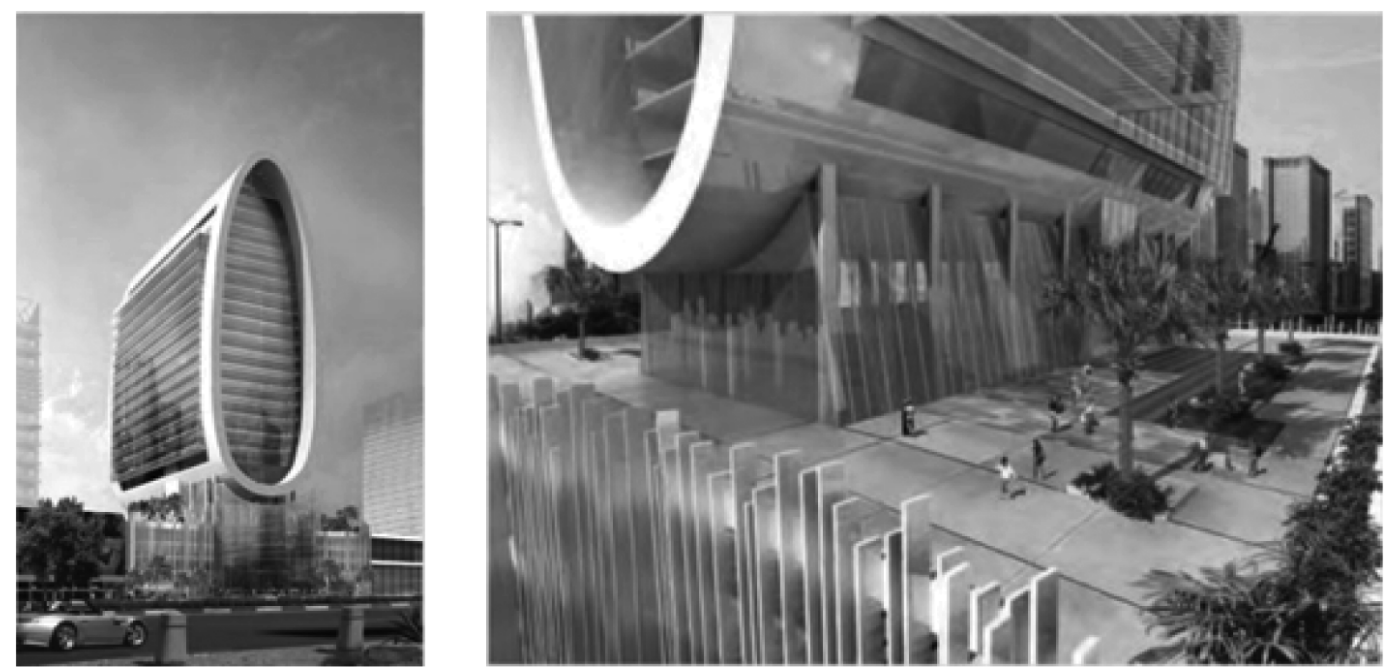

Fig. 6. DSEC Commercial Tower, Dubai, UAE, 2010

[Рис. 6. DSEC Коммерческая башня, Дубай, ОАЭ, 2010] 


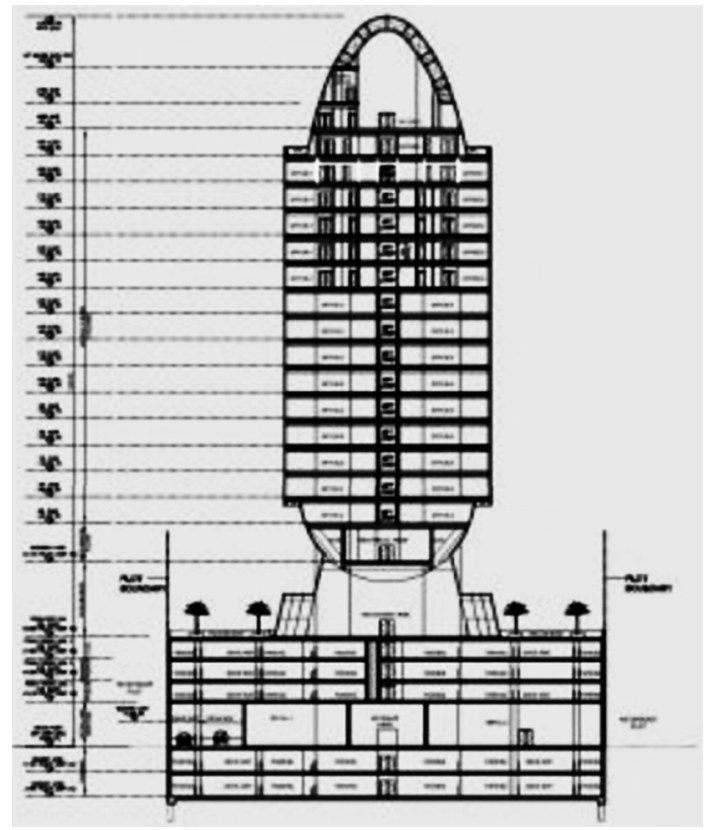

Fig. 7. A General Section

[Рис. 7. Общий раздел]

There are many other modern commercial buildings in the Middle East and many other unrealized projects, most of which are carbon critical designs with outstanding sustainability solutions but unfortunately cannot all be included in this short article.

\subsection{Residential Buildings Within The Business District}

One of the main problems in Business districts is that after work hours they become empty, which in its turn make a vital part of the city awfully quiet and empty in the evenings, turning the zone to a ghost-like area, thus, making it unpleasant for the few who reside within a business district, not to mention the waste of using a well-built area. Therefore, it is more desirable to build mix-use buildings (residential and commercial) which will allow a building and the Business district area to stay alive after work hours. However, more often we see all-residential buildings surround the business district or are located within the same zone. Such examples can be found in Dubai and many other international business hubs. Some of the examples in Dubai are.

\subsection{Princess Tower}

The princess tower (fig. 8) is one of the important buildings in Dubai and in the world, as it was the tallest residential building in the world until 2015 . It is now the $20^{\text {th }}$ tallest building in the world and the second in Dubai. Princess tower is located in Dubai Marina area, Dubai, UAE. With its simple square shaped floor plan (fig. 9) it arises for 101 floors overground and 6 underground, the total height of the tower is $413.4 \mathrm{~m}$. It is one of the few skyscrapers that are residential only and it contains 957 parking spots and 763 units which are; two, three and four bedroom apartments, duplex villas, and penthouses. The 
building also contains swimming pools, a sauna club, a gymnasium and a children's day care nursery. In addition; it has a mosque that is exclusive to the tower's residents and eight retail outlets which provide services to the building's residents. It took about 7 years to finish construction which started in 2005 with a budget of 210 million USD adding a remarkable skyscraper to the modern city of Dubai.

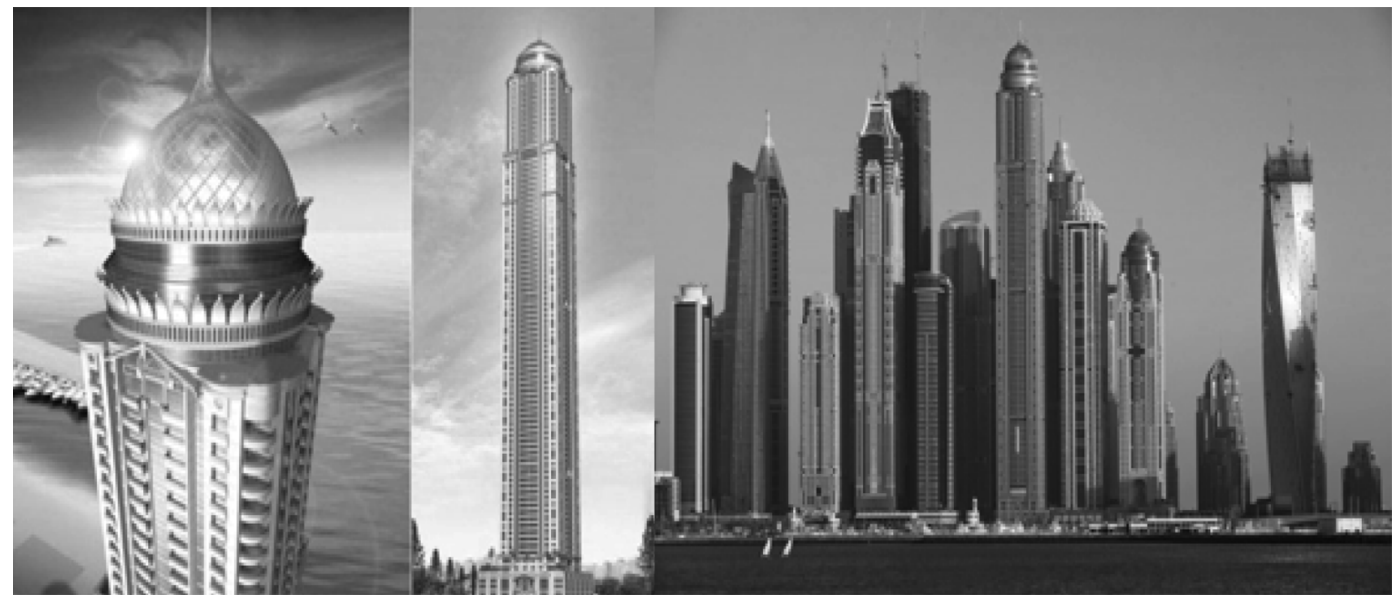

Fig. 8. Princess Tower, Dubai, UAE, 2012

[Рис. 8. Башня Принцессы, Дубай, ОАЭ, 2012]

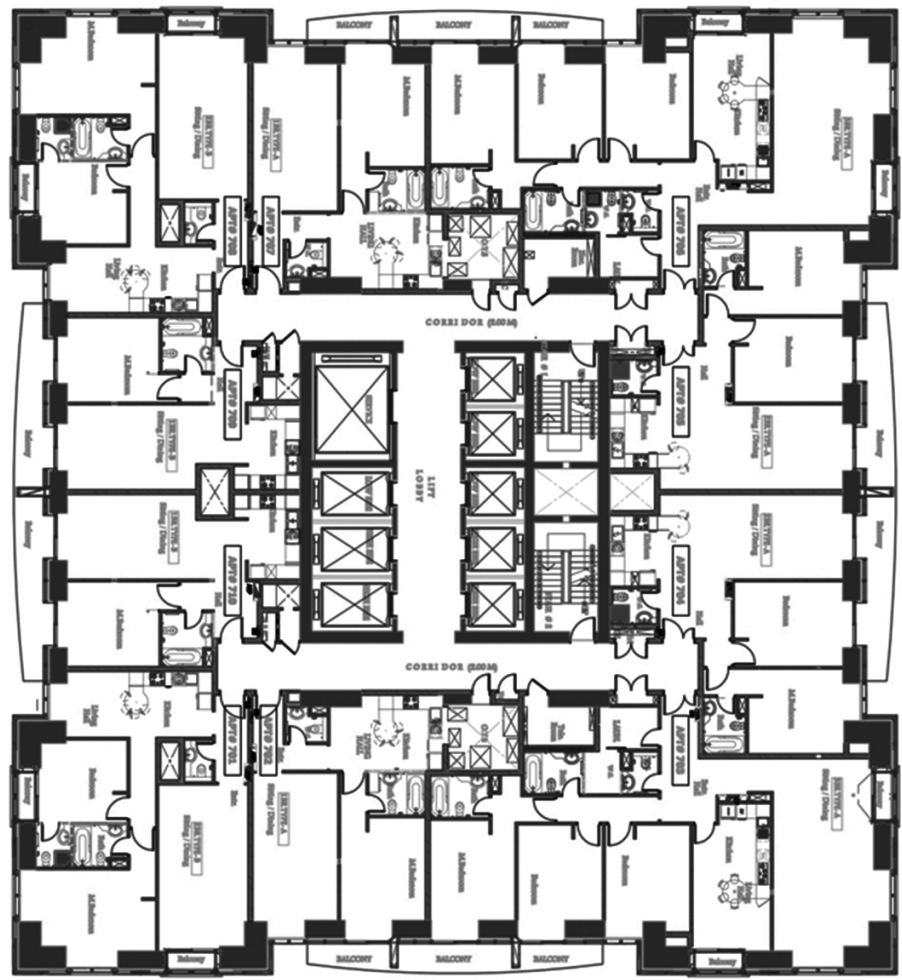

Fig. 9. Princess Tower, a typical floor plan (7-22)

[Рис. 9. Башня Принцессы, Типичный план этажа (7-22)] 


\subsection{2. $21^{\text {st }}$ Century Tower}

Located in Dubai, UAE, $21^{\text {st }}$ Century Tower (fig 10) is yet another all-residential tower. Upon its completion in 2003 it was given the title of the tallest residential building which was later given to Eureka Tower in Melbourne, Australia. The total height of the tower is $269 \mathrm{~m}$ with an approximate floor area of $1350 \mathrm{~m}^{2}$. It contains 55 floors overground and 4 underground, in addition, the building provides 412 parking places for its residents in an adjacent 9-level car park. The building provides all needed services for its residences (which are mainly the crew of Emirates airlines) like a rooftop swimming pool and a gym.

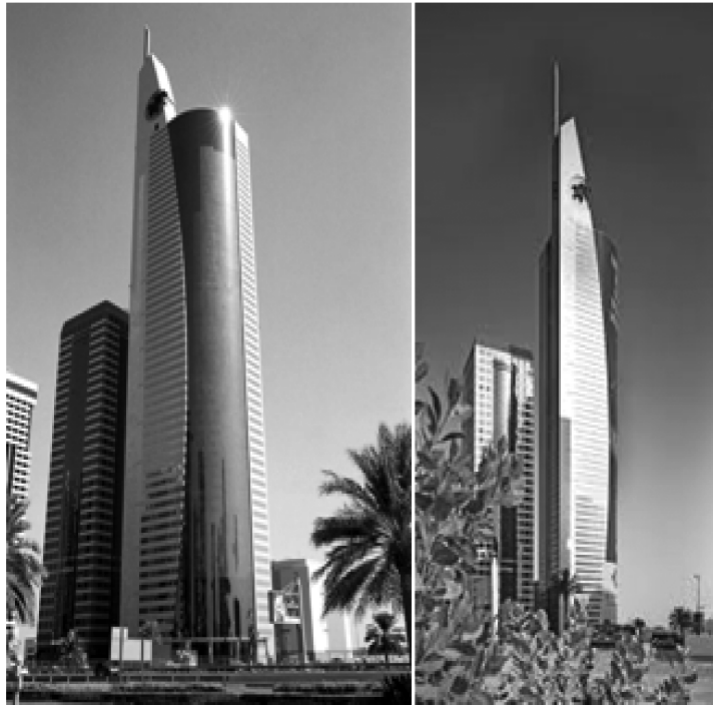

Fig. 10. $21^{\text {st }}$ Century Tower, Dubai, UAE, 2003

[Pис. 10. Башня 21-го века, Дубай, ОАЭ, 2003]

\section{PROBLEMS AND FUTURE EXPECTATIONS}

The architecture in the Arabian Gulf has faced so many challenges, especially during the global recession. Many other challenges faced the realization of many projects which were designed but never realized; as all these projects need enormous amount of funding which was nowhere to be found even though most of the projects tend to have many sources of renewable power which lower the cost of using the facility, many projects were left unfunded and remained as blueprints.

Dubai is known for its high-tech designs and architecture, it continues to grow adding more technology each time, funders from all over the world are getting interested in investing over there which will solve the funding problems faced earlier which in its turn allows architecture to flourish.

One of the other challenges facing the architecture in the Arabian Gulf is the lack of space to construct; one of the solutions was the construction of artificial islands which provided more space to have horizontal spread instead of vertical. But that is a limited source as well and is not practical due to its limitation. On the other hand, the desert which has extreme high temperatures could be somehow rehabilitated and turned into a habitable space in the future. 


\section{CONCLUSION}

Our new style of life demands radical changes of our cities and buildings. Environmental solutions and sustainability must be present in all new projects as we must pay attention to the levels of carbon emission and make all building as self-sufficient as possible by using renewable energy from the surrounding environment and lowering the cost of construction by using domestic materials in order to get project more beneficial and productive.

Many great examples are to be found in the world- even though some are unrealized - such as X-Change Gateway in Dubai, UAE which is a zero-carbon super tower that provides 6Mw using wind energy. Such examples are the future of architecture not only for skyscrapers but also for all types of buildings and constructions bringing architecture to the future.

\section{REFERENCES}

[1] Atkins Architects. Atkins: Architecture \& Urban Design: Selected \& Current Works 2011. Images Publishing. 01 January 2011.

[2] www.atkinsglobal.com [online]. Burj Al Arab. https://www.atkinsglobal.com/en-gb/projects/ burj-al-arab.

[3] www.atkinsglobal.com [online]. Atkins at a glance. https://atkinsglobal.co/en-gb/about-thegroup/atkins-at-a-glanct. 23 March 2015.

[4] www.emporis.com [online]. Al Rostamani Residential and office building. Emporis. https://www. emporis.com/buildings/212000/al-rostamani-building-dubai-united-arab-emirates.

[5] www.emporis.com [online]. Tiffany Towers. Empois. https://www.emporis.com/buildings/240181/ tiffany-towers-dubai-united-arab-emirates

[6] www. architect.co.uk [online]. DSEC Commercial Tower Dubai, Skyscraper. e-architect https:// www.e-architect.co.uk/dubai/dsec-commercial-tower. 12 September 2016.

[7] Government of Dubai. Duabi 2020 Urban Masterplan. www.dm.gov.ae

[8] www.emporis.com [online]. Princess Tower. Emporis. https://www.emporis.com/buildings/220471/ princess-tower-dubai-united-arab-emirates

[9] www.emporis.com [online]. $21^{\text {st }}$ century Tower. Emporis. emporis.com. https://www.emporis. com/buildings/186985/21st-century-tower-dubai-united-arab-emirates

[10] Alexey Shipitsin. Top 20 - masterpieces of concrete and glass. www.psdom.ru. [online]. http:// psdom.ru/catalog/top-20-shedevry-iz-betona-i-stekla

(C) Razin A.D., Alhalabi Z.Sh., Khalil I., 2017

\section{Article history:}

Received: 28 February 2017

Accepted: 14 March 2017

For citation:

Razin A.D., Alhalabi Z.Sh., Khalil I. (2017) The study of business centers in the Arabian Gulf: residential, offices, and commercial buildings. RUDN Journal of Engineering Researches, 18(2), 219-229.

\section{Bio Note:}

Info was not provided. 


\title{
ИССЛЕДОВАНИЕ БИЗНЕС-ЦЕНТРОВ В АРАБСКОМ ЗАЛИВЕ: ЖИЛЫХ, ОФИСНЫХ И КОММЕРЧЕСКИХ ЗДАНИЙ
}

\author{
А.Д. Разин, З.Ш. Алхалаби, И. Халиль \\ Российский университет дружбы народов \\ ул. Миклухо-Маклая, 6, Москва, Россия, 117198
}

Современная архитектура Арабского залива стала международным значком после завершения Бурдж Аль-араб в 1999 году. С тех пор появились много более современных зданий, которые были построены для размещения многочисленных международных компаний проживающих или ветвящиеся в Арабском заливе, особенно в Дубае.

В этой статье рассмотрены несколько примеров современной архитектуры Арабского залива, некоторые из многих удивительных проектов были реализованы, наряду с кратким введением, с какими проблемами сталкивается архитектура в Арабском заливе, и что будущее кажется подобное.

Ключевые слова: коммерческие здания, офисы, Ближний Восток, Дубай, Арабский залив, архитектура, и углеродные критические дизайны

\section{СПИСОК ЛИТЕРАТУРЫ}

[1] Архитекторы Аткинса. Аткинс: архитектура и городской дизайн: выбранных и текущих работ 2011. Изображения Публикации. 01 января 2011 года.

[2] www.atkinsglobal.com [Электронный ресурс]. Бурдж Аль-араб. https://www.atkinsglobal. com/en-gb/projects/burj-al-arab

[3] www.atkinsglobal.com [Электронный ресурс]. Аткинс на первый взгляд. https://atkinsglobal. co/en-gb/about-the-group/atkins-at-a-glanct (дата обращения: 23 марта 2015).

[4] www.emporis.com [Электронный pecypc]. Аль Ростамани жилого и офисного здания. Эмприос. https://www.emporis.com/buildings/212000/al-rostamani-building-dubai-united-arabemirates

[5] www.emporis.com [Электронный pecypc]. Башня Тиффани. Эмприос. https://www.emporis. com/buildings/240181/tiffany-towers-dubai-united-arab-emirates

[6] сайт www.архитектор.ко.uk [Электронный ресурc]. DSEC Коммерческая Башня Дубая, небоскреб. э-архитектор https://www.e-architect.co.uk/dubai/dsec-commercial-tower (дата обращения: 12 сентябрь 2016).

[7] Государство Дубая. Городской Дубая 2020 Генеральный План. www.dm.gov.ae

[8] www.emporis.com [Электронный pecypc]. Принцесса Башня. Эмприос. https://www.emporis. com/buildings/220471/princess-tower-dubai-united-arab-emirates

[9] www.emporis.com [Электронный ресурс]. Башня 21-го века. Эмприос. emporis.com. https:// www.emporis.com/buildings/186985/21st-century-tower-dubai-united-arab-emirates

[10] Шипицин Алексей. ТОП-20 - шедевры из бетона и стекла. www.psdom.ru [Электронный pecypc]. http://psdom.ru/catalog/top-20-shedevry-iz-betona-i-stekla

\section{История статьи:}

Дата поступления в редакцию: 28 февраля 2017

Дата принятия к печати: 14 марта 2017 


\section{Для цитирования:}

Разин А.Д., Алхалаби З.Ш., Халиль И. Исследование бизнес-центров в Арабском заливе: жилых, офисных и коммерческих зданий // Вестник Российского университета дружбы народов. Серия «Инженерные исследования». 2017. Т. 18. № 2. С. 219-229.

Сведения об авторах:

Сведения не предоставлены. 